\title{
IMPLEMENTATION OF SWOT ANALYSIS IN HOSPITAL MANAGEMENT USING THE JKN-KIS SERVICE CONCEPT
}

\author{
Abednego Albert ${ }^{*}$, Syah Tantri Yanuar Rahmat \\ University of Esa Unggul, Jakarta, Indonesia \\ *E-mail: albert abednego@yahoo.com \\ ORCID: 0000-0003-4401-7931
}

\begin{abstract}
The hospital industry changed dramatically after the JKN program was implemented in 2014. This change should be well supported because the conventional system of health services (fee for service) makes it difficult for people to get good health service if they do not have enough money. Moreover, health is basically guaranteed by the government which is formulated in the Law. Finally, it was recently implemented and experienced many obstacles. Not many hospitals can quickly adapt to the changes in the health industry in Indonesia. Bundle budgeting is a very serious problem, so that many hospital cash flows are not appropriately maintained. There has often been news found in recent years about hospitals being sold because they were unable to adapt to these changes. The big change that must be made to survive in the JKN era is management of hospital operations with efficiency and effectiveness that does not exclude service quality. Operational excellence is the key to the success of hospital management. However, to achieve this success, a strong and accurate analysis is needed so that the changes are implemented correctly. Hospital management analysis can apply SWOT analysis. SWOT analysis is a tool commonly used in companies that is ultimately intended to get the best strategy.
\end{abstract}

\section{KEY WORDS}

Bundle budgeting, operational excellent, service, quality.

JKN-KIS refers to Jaminan Kesehatan Nasional - Kartu Indonesia Sehat (National Health Insurance - Healthy Indonesia Card).

At the beginning of Indonesian Independence Day in the 1950s, all health expenditures came from out of pocket, which would later be replaced by the government. This method is known as restitution or reimbursement. In 1970, the claim system was imposed which caused waste in the financing of health. This financing method continues to grow and changes in each era to date. The improvement process continues to be pursued to get the ideal financing system.

National Health Insurance (JKN) is a government program that aims to provide overall health insurance certainty for all Indonesian people to live healthy, productive and prosperous lives. This program is a product of Law No.40 of 2004 concerning the National Social Security System and Law No.24 of 2011 concerning the Social Security Administrator (BPJS). The mandate of article 60 paragraph 1 states that starting January 1, 2014, Social Security Administrator for Health (BPJS Kesehatan) began operating to organize national health insurance.

The existence of the National Health Insurance (JKN) program is expected to make people more prosperous. The journey to the 4th year of the implementation of the National Health Insurance shows that most of the program participants were satisfied with the benefits of the National Health Insurance program. The report in 2017 shows a relatively high level of satisfaction and service for patients. However, there are some things that still need improvement; for instance, tiered referrals, patients having difficulty obtaining nursing beds, patients are not allowed to consult several doctors with different disciplines at one visit, patients are asked to control for trivial matters, queues of JKN patients are relatively longer 
than general patients, and a relatively long waiting time for certain actions (Nofrizal, 2017; Nursafa \& Balqis, 2015).

The JKN program increases the number of patients in government and nongovernment hospitals (Sastradimulya et. al., 2015). In addition, an increase in the number of patients also has a concomitant impact such as poor service quality. Disagreements in coding diagnoses and episodes in patient visits in hospitals often occur.

INA-CBG's Tariff. Indonesia Case Base Group is a benchmark tariff that is paid by the Social Security Administrator for Health (BPJS Health) to health facilities. INA-CBG's itself is determined by data from case mix and case mix is determined by data from the hospital. Disease making activities that have been handled with clinical pathways that are in accordance with INA-CBG's tariffs must be carried out. Socialization and implementation for all units and levels in health facilities is also needed. The review of INA-CBG's tariffs needs to be carried out continuously without differentiating hospital classes to become a necessity and the basis for calculations is based on the clinical pathway. For private hospitals, especially, higher rates from government hospitals need to be provided. It is a realistic thing because hospitals have to pay electricity bills and employee salaries, buy medical equipment, and so on.

Problems that are often experienced by hospitals in implementing National Health Insurance are the high bills that are rejected, the length of the verification process, and the determination of extra payment unilaterally (Feriawati \& Kusuma, 2015).

Verification in the Social Security Administrator for Health (BPJS Kesehatan) consists of verification of administrative claims and verification of health services. The stages of claim verification include:

- Verification of Health Administration. It examines the suitability of claim documents consisting of Participant Eligibility Letters (SEP), inputted data in the INA-CBG's application, and other supporting documents;

- Verification of Service Administration.

The things that must be considered in service administration are:

- Endorsement from the medical committee for level 3 severity;

- The suitability of the doctor in charge of services (DPJP) with the diagnosis of the patient;

- The suitability of DPJP with operational actions;

- Suitability of the hospital type with the competence of doctors in the hospital;

- Prevention of unbundling in claims;

- Attention to readmission for the same disease.

Things to consider in the Case mix Main Group (CMGs):

- Severity according to the type and competence of the Hospital;

- Verifiers ensure compatibility of diagnoses and procedures in ICD 9 and ICD 10;

- Cases where the diagnosis is upright use control coding at the next meeting;

- Patients who received outpatient services and continued with hospitalization on the same day can pay for it in one episode of hospitalization.

One effort to accelerate the verification process is to rely on an IT system that is superior in terms of speed, accuracy and transparency. However, in an effort to build an integrated system, there are currently several obstacles, as follow:

- The JKN information system is not integrated with PCARE, SEP, SIMRS, LUPIS, and BPJS Verification;

- Not all hospitals are able to create integrated systems;

- Bridging activity between systems has not been carried out.

Delay verification consists of various problems in filing claims. Submission of claims is categorized in two types, consisting of good claims administration (non-problematic) and problematic claims administration (Nurdiah \& Iman, 2016). In the good claims or nonproblematic administration, settlement of claims can be carried out in accordance with the Service Level Agreement (SLA) in the contract. 
Delay in hospital payments is caused by many problems; for example, irregular step carried out by hospital staff in filing claims, subsequent claims, incomplete files accompanying claims, disagreements in coding rules. There are 3 parties that can influence hospital claims which consist of hospital management, clinician, and hospital coder. Hospital management can issue internal policies that affect the clinical and coder in the form of regulations such as restrictions on measures, and restrictions on the types of drugs that indirectly can affect the clinical pathway. Management policies can affect coders such as policies in using certain codes (Putra \& Kusumo, 2016).

All parties have a certain role in the smooth process of billing claims. The doctor is in charge of completing a medical resume. Next, the coder will translate the medical resume in the code that is available on ICD 10 and ICD 9 which will be translated by the coders into the INA-CBG's grouper code. The hospital claim officer ensures that the claim file is complete and then it will be verified by the hospital's internal verifier before being submitted to the verifier of BPJS Kesehatan.

Case Mix Team. It was a team consisting of several people who had different professional backgrounds in a hospital led by a doctor. In the JKN era, this case mix team will become an important pillar and source of information for other units and as a data analysis center for services, especially the rules of BPJS Kesehatan that can change rapidly.

The team's main task is to ensure that the hospital case flow can run smoothly. The team also educates medical and non-medical staff about the strategies that must be conducted to reduce waste so that services become effective and efficient. High authority is important in the success of carrying out their role because it will affect and even regulate other divisions. It will be difficult if the function is not supported by the authorities.

Managerial Implications. Managerial implications can be seen from the results of the SWOT analysis owned by ESUMMI Hospital. Based on the big picture of the strategy produced by the SWOT analysis, an important pillar in the implementation in the field is strengthening the case mix team, operational excellence, and service excellent. One method that can be used is using LEAN Management. It is conducted by eliminating waste/ work that has no benefits and making efforts to innovate continuously.

Leadership from the hospital leadership is also needed, because innovation and creativity will occur and grow if top-to-bottom is changed to bottom-to-top management. It becomes relevant because the one who understands the problems and solutions that occur in the field is the staff who work in the area itself. Therefore, if a head or leader gives freedom to staff to express solutions and ideas without feeling guilty when expressing that opinion with appreciation, then the company will develop.

The advantage for ESUMMI Hospital in implementing bottom-to-top management is to map the problems in each business process that exist by staff who are in charge of their respective units and make improvements to the problems found. Hospital operations will automatically continue to develop and innovate towards operational excellent.

Operational excellence is often associated with efficiency and ultimately sacrificing service. In this case, it does not happen because in the field of quality service, the quality of a service will be an absolute thing especially in terms of the service of living things. Excellent service and quality are serious concerns in the health industry. Management must be firm in analyzing useless things.

SWOT Analysis. SWOT analysis is a systematic identification of various factors to formulate a company's strategy (Kotler, 2000). This analysis is based on internal and external elements:

The strength possessed by a company in this case is the hospital industry including its resources, skills, and other advantages to competitors; for instance, technology and team case mix skills.

Weakness in this case is everything that can hinder or impede the company to achieve its objectives including the absence of skills or the leadership possessed by each unit in the hospital; for instance, there are specialist doctors who find it difficult to understand service concept in the JKN era. 
Opportunity is everything that can help a company to achieve its vision and mission from outside the hospital environment; for instance, government policies and the increasing levels of economic growth.

Threat is everything that comes from outside the company or hospital environment that can prevent the hospital from achieving its objectives; for instance, the emergence of similar competitors who will become business rivals.

Data analysis of this study is descriptive research that aims to provide a description of the research subject based on the acquisition of variable data. The analysis technique used to assess ESUMMI Hospital is the SWOT matrix. Stages to determine the steps in determining the strategy are carried out by utilizing the strengths and opportunities to overcome the threats and weaknesses they have that include:

- Identification of internal and external factors. It is needed to assess to what extent the hospital's position on the SWOT analysis;

- Perform analysis using the SWOT matrix. It can clearly illustrate the opportunities and threats as the external factors, as well as strengths and weaknesses for internal factors to be adjusted when the strategy is implemented.

Table 1 - External Factors of ESUMMI Hospital

\begin{tabular}{|c|c|c|c|c|}
\hline \multicolumn{2}{|r|}{ EXTERNAL STRATEGY FACTOR } & \multirow{2}{*}{ WEIGHT } & \multirow{2}{*}{ RATING } & \multirow{2}{*}{ SCORE } \\
\hline $\mathrm{NO}$ & OPPORTUNITY & & & \\
\hline 1. & COB cooperation with private and insurance companies & 0.15 & 4 & 0.6 \\
\hline 2. & $\begin{array}{l}\text { Specializing in becoming a BPJS Hospital (doing business in work } \\
\text { volume) }\end{array}$ & 0.10 & 4 & 0.4 \\
\hline 3. & Patient plan therapy as a guide to services at the Hospital & 0.10 & 4 & 0.4 \\
\hline 4. & Utilization and optimization of BPJS patient services will get good benefits & 0.05 & 3 & 0.15 \\
\hline 5. & $\begin{array}{l}\text { Government regulation regarding BPJS where the Hospital is a reference } \\
\text { place for First Level Health Facilities }\end{array}$ & 0.05 & 4 & 0.2 \\
\hline 6. & $\begin{array}{l}\text { The hospital that specializes in BPJS will get free advertising from the } \\
\text { specificity of the business }\end{array}$ & 0.05 & 3 & 0.15 \\
\hline \multicolumn{2}{|c|}{ TOTAL } & 0.5 & & 1.90 \\
\hline & THREAT & & & \\
\hline 1. & Low BPJS tariffs & 0.15 & 1 & 0.15 \\
\hline 2. & Hospitals must be accredited to join BPJS (need a big cost) & 0.10 & 2 & 0.20 \\
\hline 3. & Lots of competition to join BPJS & 0.10 & 1 & 0.10 \\
\hline 4. & Difficulty in getting a cooperative specialist doctor & 0.05 & 1 & 0.05 \\
\hline 5. & Technology turbulence in the medical industry & 0.05 & 1 & 0.05 \\
\hline 6. & Pending claim in BPPJS & 0.05 & 2 & 0.10 \\
\hline \multicolumn{2}{|c|}{ TOTAL } & 0.5 & & 0.65 \\
\hline \multicolumn{2}{|c|}{ O-T DIFFERENCE } & & & 1.25 \\
\hline
\end{tabular}

Table 2 - Internal Factors of ESUMMI Hospital

\begin{tabular}{|c|c|c|c|c|}
\hline \multicolumn{2}{|r|}{ INTERNAL STRATEGY FACTOR } & \multirow{2}{*}{ WEIGHT } & \multirow{2}{*}{ RATING } & \multirow{2}{*}{ SCORE } \\
\hline NO & STRENGTH & & & \\
\hline 1. & Have competent labors & 0.2 & 4 & 0.8 \\
\hline 2. & Have a competent case mix team & 0.2 & 4 & 0.8 \\
\hline 3. & Service excellent & 0.05 & 4 & 0.2 \\
\hline 4. & Integration of First Level Health Facilities & 0.05 & 3 & 0.15 \\
\hline \multicolumn{2}{|c|}{ TOTAL } & 0.5 & & 1.95 \\
\hline & WEAKNESS & & & \\
\hline 1. & $\begin{array}{l}\text { The tariff of INA-CBG's BPJS is still not in line with health services in } \\
\text { hospital }\end{array}$ & 0.2 & 2 & 0.4 \\
\hline 2. & The quality of patient safety & 0.1 & 1 & 0.1 \\
\hline 3. & Uncooperative specialist doctors & 0.2 & 1 & 0.2 \\
\hline \multicolumn{2}{|c|}{ TOTAL } & 0.5 & & 0.7 \\
\hline \multicolumn{2}{|c|}{ S-W DIFFERENCE } & & & 1.25 \\
\hline
\end{tabular}


Table 3 - SWOT Matrix of ESUMMI Hospital

\begin{tabular}{|c|c|c|}
\hline $\begin{array}{l}\text { Internal Factors } \\
\text { External Factors }\end{array}$ & $\begin{array}{l}\text { Strengths (S): } \\
\text { 1. Having management experience in } \\
\text { the JKN era } \\
\text { 2. Having a competent case mix team } \\
\text { 3. Using the best operational } \\
\text { management } \\
\text { 4. Being integrated with First Level } \\
\text { Health Facilities / Satellite Clinics } \\
\text { 5. Service Excellent }\end{array}$ & $\begin{array}{l}\text { Weakness (W): } \\
\text { 1. Great effort to adapt to INA- } \\
\text { CBG's tariffs } \\
\text { 2. Quality of patient safety } \\
\text { 3. Uncooperative specialist } \\
\text { doctors }\end{array}$ \\
\hline $\begin{array}{l}\text { Opportunities (O): } \\
\text { 1. COB cooperation with private } \\
\text { and insurance companies } \\
\text { 2. Specializing in becoming a } \\
\text { BPJS Hospital (doing business } \\
\text { in work volume) } \\
\text { 3. Patient plan therapy as a } \\
\text { guide to services at the Hospital } \\
\text { 4. Utilization and optimization of } \\
\text { BPJS patient services will get } \\
\text { good benefits } \\
5 \text {. Government regulation } \\
\text { regarding BPJS where the } \\
\text { Hospital is a reference place for } \\
\text { First Level Health Facilities } \\
6 \text {. The hospital that specializes } \\
\text { in BPJS will get free advertising } \\
\text { from the specificity of the } \\
\text { business }\end{array}$ & $\begin{array}{l}\text { S-O Strategy: } \\
\text { - Specializing in becoming a hospital for } \\
\text { participants of JKN service that has a } \\
\text { competent case mix team (O2, S2) } \\
\text { - Conducting cooperation with integrated } \\
\text { first level health facilities so that it will } \\
\text { improve utilization and optimization of } \\
\text { services for JKN patients (S4, O4) }\end{array}$ & $\begin{array}{l}\text { W-O Strategy: } \\
\text { - Increasing networks of other } \\
\text { funding sources such as private } \\
\text { and insurance companies using } \\
\text { COB (systems W1, O) } \\
\text { - Educating the Hospital's internal } \\
\text { medical personnel to strengthen } \\
\text { the plan therapy (W1, O3) }\end{array}$ \\
\hline $\begin{array}{l}\text { Threats }(T) \text { : } \\
\text { 1. INA-CBG's tariffs will change } \\
\text { every } 2 \text { years } \\
\text { 2. Not many doctors understand } \\
\text { the concept of JKN } \\
\text { 3. Turbulence in the medical } \\
\text { industry technology } \\
\text { 6. JKN patients are increasing }\end{array}$ & $\begin{array}{l}\text { S-T Strategy: } \\
\text { - Implementing excellent Operational \& } \\
\text { Service so that it will be effective and } \\
\text { efficient for each case of changing times } \\
\text { (T1, S3) } \\
\text { - Increasing the value proposition/ } \\
\text { playing the volume (T6, S4) }\end{array}$ & $\begin{array}{l}\text { W-T Strategy: } \\
\text { - Conducting recruitment on a full } \\
\text { timer doctor who understands the } \\
\text { concept of JKN (T4, W3) }\end{array}$ \\
\hline
\end{tabular}
implement.

After looking at the table above, there are seven alternatives that the company can SO Strategy:

- Focusing on serving JKN patients by relying on competent case mix teams;

- Having collaboration with integrated first level health facilities to improve utilization and optimization of services to JKN participants. WO Strategy:

- Increasing cooperation with other agencies such as private insurance, BPJS Ketenagakerjaan and other companies;

- Continually educating internal hospital staff including medical and non-medical staff so that they know and understand the concept of JKN services.

ST strategy:

- Implementing excellent operation and service at each service without ignoring service quality;

- Serving JKN participants in large quantities.

WT Strategy:

- Conducting recruitment on medical and non-medical staff who understand the concept of JKN.

The method used in this study is an evaluation of programs and management that currently have been running in most hospitals in Indonesia. 


\section{CONCLUSION}

SWOT analysis is a stage of matching the parts of the second stage in which the final result aims to determine the strategies used by companies that are considered to have a large leverage which is assessed objectively. Looking at strategies that can be used and matched using the SWOT matrix for the strategy of strengthening the case mix team and strengthening hospital services with operational and service excellence is very vital. It can be confirmed by using other tools in order to produce strategies that are related between the tools with each other. Strengthening the case mix team and excellent operations are two strategies chosen from many strategies aside from the objective results of the tool. However, it is also the most difficult thing to be imitated by competitors. Therefore, the sustainability of the ESUMMI Hospital business in this case is maintained more appropriately.

\section{REFERENCES}

1. Feriawati, P., \& Kusuma, A. P. (2015). Faktpr-Faktor Keterlambatan Pengklaiman BPJS di Rumah Sakit Bhayangkara Semarang Tahun 2015.

2. Kotler,P., 2000, Marketing Management Analysis, planning, implementation and control, $8^{\text {th }}$ edition, Pearson Prentice Hall, New Jersey.

3. Nofrizal, N. (2017). Strategi Tumbuh and Bersaing Di Industri Asuransi (Studi Kasus Pada BPJS Ketenagakerjaan Pekanbaru). Benefit: Jurnal Manajemen and Bisnis, 2(1), 78-91.

4. Nurdiah, R. S., \& Iman, A. T. (2016). Analisis Penyebab Unclaimed Berkas BPJS Rawat Inap di RSUD Dr. Soekardjo Tasikmalaya. Jurnal Manajemen Informasi Kesehatan Indonesia, 4(2).

5. Nursafa, A., \& Balqis, S. P. (2015). Faktor Yang Berhubungan Dengan Pemanfaatan Pelayanan Kesehatan Pasien BPJS Kesehatan Di Puskesmas Jumpandang Baru. Jurnal Penelitian(Online) http://repository. unhas. ac. id/handl e/123456789/14094. Di akses pada, 26.

6. Putra, D. A. A., \& Kusumo, M. P. (2016). Model Verifikasi Klaim BPJS Pasien Rawat Inap di RS PKU Muhammadiyah Gamping. In Prosiding Interdisciplinary Postgraduate Student Conference.

7. Sastradimulya, F., Nurhayati, E., \& Susanti, Y. (2015). Hubungan tingkat pengetahuan pasien tentang Jaminan Kesehatan Nasional dengan status kepesertaan BPJS. 